\title{
PERKAWINAN ANTAR WANGSA : ANALISIS PERWARISAN DALAM ADAT BALI (Kajian Masyarakat Aktif Bali)
}

\author{
A.A. Istri Ngurah Dyah Prami dan Nazrina Zuryani ${ }^{1}$ \\ Universitas Gadjah Mada dan Universitas Udayana \\ dyahprami@yahoo.co.id dan nazrinazuryani@yahoo.com
}

\begin{abstract}
Adat regulations in Bali is not only contradict dualism of men and women as purusa pradana, it gives the mipil (registration at village level) to men. Besides this patriarchy system, in marriage especially there is alsowangsa influence; they are the groups of Brahmin, Ksatria, Waisya and Sudra. Each group as Etzioni ${ }^{2}$ (1968)suggests taking up different positions in Balinese active society. They are bounded in patterns of banjar with Awig-awig (written agreement), in familial (menyama braya) or clan patterns, and complex marriage engagements. Ategen asuwun is a newly concept of inheritance (2 parts for sons and 1 part for daughters) based on marriage engagement for contemporary Balinese adat regulations. Wangsa system in adat marriage is the impetus of Balinese women's problems. Marriage is displacing women as limited ninggal kedaton from theirfathers temple to their husband's temple. Social construction in society has prohibited a high caste/wangsa woman to marry lower caste man (nyerorod marriage). This wangsa system has limited Balinese women's right to inherit even they are in the same clan and wangsa. As a result, never marriage woman is one of the choise to get her inheritance. In the anuloma marriage where as a high caste man marry a lower caste woman, the concept of limited ninggal kedaton is still taking place and modern familial system has given daughers the one part of tatadan inheritance. However, the anomaly is given to a newly religious converted woman by marriage where is full ninggal kedaton gives no inheritance at all to her.
\end{abstract}

Key words: Balinese women, Intercaste marriage, Inheritance rights

${ }^{1}$ Makalah ini hasil kolaborasi mahasiswi S2 dan mantan dosen pembimbing yang masing-masing makalah telah disajikan dalam Konferensi Internasional Feminisme tanggal 2324 September 2016 yang diselenggarakan oleh Jurnal Perempuan di Arion Swiss-Belhotel Kemang Jakarta.

2Lihat bab 15 pada buku Margareth M Poloma, Sosiologi Kontemporer (Rajawali Pers, 2013) hal 352-373. 


\section{PENDAHULUAN}

Perkawinan menjadi satu tahap tersendiri pada masyarakat Hindu di Bali yang mengenal empat fase di dalam siklus kehidupan manusia yang disebut dengan Catur Asrama $^{3}$. Keempat fase tersebut meliputi tahap brahmacari, grehasta, wanaprasta dan bhiksuka (sanyasin). Brahmacari merupakan tahap dimana seseorang melakukan usaha menuntut ilmu pengetahuan. Grahasta disebut juga sebagai tahap berumah tangga. Wanaprasta merupakan tahap persiapan menuju masa bhiksuka. Pada tahap ini seseorang mulai melepaskan segala kewajibannya.Terakhir adalah tahap Bhiksuka dimana seseorang mulai melepaskan unsur keduniawian yang mengikatnya. Perkawinan merupakan bagian dari masa Grahasta. Perkawinan menjadi suatu penanda adanya peralihan dari masa dewasa menuju masa berumah tangga. Ada tiga aspek penting di dalam perkawinan, yaitu aspek sosial, religius, dan hukum.

Perkawinan Adat Bali tidak terlepas darikonsep Purusa dan Pradana yang berlaku dalam kehidupan masyarakat Bali. Kedua konsep tersebut merujuk pada kedudukan laki-laki dan perempuan dalam kehidupan masyarkat setempat. Konsep yang menurut Korn ${ }^{4}$ sebagai sistem kekeluargaan di Bali yang memiliki keistimewaan, yaitu mengusahakan selama mungkin kewajiban-kewajiban di dalam menjalankan keagamaan yang dijalankan oleh pretisentana (keturunan) laki-laki menurut garis lurus. Bahkan jika dalam suatu keluarga tidak dikaruniai oleh anak laki-laki, maka sangat dimungkinkan untuk mengangkat anak (pemerasan anak sentana).

Umumnya perkawinan adat Bali menganut sistem patrilinial, yang mana garis keturunan mengikuti garis keturunan laki-laki (ayah). Dengan kata lain bahwa, perempuan yang telah menikah akan mengikuti keluarga suaminya.Meskipun secara umum sistem patrilinial berlaku dalam perkawinan adat Bali, akan tetapi dalam beberapa kasus sistem matrilinial dapat ditemui dalam perkawinan nyeburin atau nyentana. Di dalam perkawinan adat Bali itu sendiri ada empat bentuk perkawinan yang biasa dilakukan, yaitu perkawinan mepadik, perkawinan kejangkepan, perkawinan merangkat atau nyerorod, dan perkawinan pada gelahang. Keempat bentuk perkawinan tersebut memiliki konsekuensi yang berbeda-beda di dalam hukum adat Bali. Hal ini mengingat, bahwa perkawinan di dalam hukum adat Bali tidak hanya memiliki konsekuensi sosial-budaya, tetapi juga juga berkaitan erat dengan aspek religius dan hukum.

Perkawinan berkaitan erat dengan tanggung jawab atau kewajiban (swadharma) seseorang terhadap keluarga maupun masyarakat. Tanggung jawab atau kewajiban tersebut berkaitan dengan aktivitas keagamaan (parhyangan), aktivitas kemanusiaan (pawongan), dan aktivitas yangberkaitan dengan pemeliharaan lingkungan (palemahan). Terkait dengan aspek sosial-budaya, perkawinan yang dilakukan oleh seseorang akan memberikannya status di dalam masyarakat. Dalam hukum adat Bali, mereka yang sudah menikah akan memperoleh pengakuan penuh dari masyarakat sebagai anggota krama desa dan berhak atas hak dan tanggung jawab yang sama seperti anggota krama desa lainnya. Di Bali perkawinan tidak hanya dipandang sebagai jembatan dalam penyatuan dua individu, tetapi juga berkaitan dengan hubungan antara keluarga dan

3Jaman, I Gede.Membina Keluarga Sejahtera (Grha Jagatdhita). Surabaya: Paramita, 1998.

${ }^{4}$ Lihat Atmaja, Jiwa. 2008. Bias Gender Perkawinan Terlarang Pada Masyarakat Bali. Denpasar: Udayana University Press, hal 2 
masyarakat. Maka dari itu, perkawinan menjadi bagian penting dalam menentukan kedudukan seseorang di masyarakat. Status yang diperoleh seseorang dari suatu perkawinan juga ditentukan olehdengan siapa perkawinan tersebut dilakukan dan bagaimana sistem wangsa di Bali sangat menentukan apakah suatu perkawinan dapat diterima atau tidak.

Tidak hanya itu, perkawinan juga berkaitan erat dengan aspek religius, yang mana perkawinan baru dianggap sah jika dilakukan berdasarkan agama yang bersangkutan. Selain itu, perkawinan yang dilakukan oleh seseorang juga menentukan tanggung jawabnya (swadharma-nya) terhadap pura keluarga dan pura desa. Anak laki-laki yang sudah menikah tidak hanya memiliki tanggung jawab terhadap masyarakat adat (krama adat) tempat dia tinggal, tetapi juga memiliki kewajiban melanjutkan persembahyangan di sanggah atau merajan keluarganya ${ }^{5}$.

\title{
2. TINJAUAN PUSTAKA
}

Perkawinan juga terkait dengan aspek hukum, baik hukum adat maupun hukum negara karena hak dan kewajiban suami isteri, termasuk didalamnya berkaitan dengan hak waris. Waris dalam bahasa Bali berarti keturunan. Ada dua istilah dalam hukum adat Bali yang berkaitan dengan hak waris, yaitu ategen dan asuwun. Ategen merupakan istilah yang digunakan untuk menggambarkan hak waris bagi anak lakilaki adalah dua bagian. Sementara asuwun merupakan istilah pembagian satu bagi anak perempuan. Istilah ategen asuwun berarti dua berbanding satu (MDP, 2011).

Etzioni (1968) menjabarkan masyarakat aktif memiliki kemampuan pengarahan kemasyarakatan (societal guidance) ${ }^{6}$ melalui self guiding yaitu pengembangan sendiri pelembagaan masyarakatnya. Salah satunya dengan MDP, yang kepanjangan dari Majelis Utama Desa Pakraman. Lembaga ini menerbitkan himpunan hasil-hasil pasamuan agung III. Sebelum adanya Pasamuan Agung III, hak waris bagi perempuan Bali tidak pernah diakui dalam hukum perkawinan adat Bali. Akan tetapi setelah Pasamuan Agung tersebut dilakukan barulah perempuan Bali memperoleh hakhaknya di dalam pernikahan.

\section{Kedudukan Perempuan dalam Perkawinan Antar Wangsa}

Wangsa atau kasta merupakan sistem sosial yang berlaku pada masyarakat Bali.Sistem tersebut didasarkan pada garis keturunan. Dalam sistem wangsa ada satu keturunan yang dianggap lebih tinggi dan ada yang dipandang lebih rendah. Demikian pula ada kelompok keturunan yang secara tradisional mendapatkan hakhak istimewa terutama dalam pergaulan adat ${ }^{7}$. Berlakunya sistem wangsa atau kasta menyebabkan timbulnya kelompok-kelompok sosial yang disebut dengan istilah Catur Wangsa. Catur Wangsa yang terdiri dari Wangsa Brahmana, Wangsa Ksatriya, Wangsa Waisya, dan Wangsa Sudra masing-masing memiliki kedudukan yang berbeda di masyarakat. Dari keempat golongan tersebut, masyarakat yang berasal dari wangsa Brahmana, Ksatriya, dan Waisya disebut sebagai golongan Triwangsa. Kelompok tersebut

\author{
5 Ibid, hal 4 \\ ${ }^{6}$ Ibid, hal 356 \\ 7 Sudantra, 2002, Wanita Bali dan Harta Benda Perkawinan, Suatu Perspektif Normatif, Jurnal
} Studi Jender Srikandi, Vol. 2 No 2 Juli 2002 
dipandang memiliki status sosial yang lebih tinggi jika dibandingkan dengan masyarakat yang berasal dari wangsa Sudra. Hal tersebut dikarenakan golongan Triwangsa dipandang sebagai kalangan bangsawan dalam masyarakat Bali. Pengelompokan berdasarkan catur wangsa ini tidak hanya mengatur status dan peran seseorang di dalam masyarakat, tetapi juga telah menimbulkan adanya stratifikasi sosial di dalam masyarakat. Dikatakan demikian karena sistem tersebut menempatkan golongan Brahmana pada struktur yang paling tinggi, kemudian diikuti oleh golongan Ksatriya, Waisya dan Sudra.

Tanpa disadari, stratifikasi sosial yang ditimbulkan dari adanya penggolongan berdasarkan caturwangsa telah menimbulkan pro dan kontra terutama jika terjadi perkawinan antarwangsa. Ada dua jenis perkawinan antarwangsa yang berlangsung dalam perkawinan adat Bali. Pertama, perkawinan yang terjadi antara laki-laki dari wangsa yang lebih tinggi dengan perempuan dari wangsa yang lebih rendah. Kedua, perkawinan yang terjadi antara perempuan dari wangsa lebih tinggi dengan laki-lakilaki dari wangsa yang lebih rendah.

Perkawinan pada prinsipnya merupakan suatu ikatan lahir bathin antara seorang pria dengan seorang wanita sebagai suami isteri dengan tujuan membentuk keluarga (rumah tangga) yang bahagia dan kekal berdasarkan Ketuhanan Yang Maha Esa. Ada dua bentuk perkawinan yang umum dilakukan dalam hukum adat Bali, pertama adalah perkawinan dimana perempuan mengikuti keluarga suami. Kedua, perkawinan nyentana/nyeburin yang mana dalam perkawinan tersebut justru pihak laki-laki yang mengikuti keluarga istri. Meskipun secara umum masyarakat di Bali menganut sistem patrilineal, tetapi perkawinan matrilineal tidak dilarang jika dilakukan (di Tabanan, Badung, Denpasar).

Dalam konteks budaya Bali yang menganut ideologi patriarkhi secara tidak langsung mengkodratkan bahwa laki-laki memiliki kedudukan lebih tinggi dibandingkan perempuan, bahwa perempuan harus dikuasai oleh laki-laki dan merupakan bagian dari harta milik lelaki ${ }^{8}$. Dengan berlakunya ideologi tersebut berimplikasi pada kedudukan perempuan dalam perkawinan adat Bali. Perkawinan adat Bali dapat dibedakan menjadi dua bentuk, yaitu perkawinan anuloma dan pratiloma. Berdasarkan kitab Menawa Dharmacastra yang merupakan kitab hukum Hindu Bali menyebutkan mengenai perkawinan anuloma dan pratiloma. Perkawinan anuloma adalah perkawinan yang dilakukan antara laki-laki dari wangsa Brahmana, Ksatrya, dan Waisya dengan perempuan dari wangsa Sudra. Sementara yang dimaksud dengan perkawinan pratiloma adalah perkawinan yang terjadi antara laki-laki dari wangsa Sudra dengan perempuan dari wangsa Brahmana, Ksatrya, dan Waisya9.

Perkawinan anuloma dan pratiloma berkaitan erat dengan sistem wangsa atau kasta yang berlaku di Bali. Pada dasarnya perkawinan adat Bali dilaksanakan menggunakan prinsip pepadan ( $p a d a=$ sama, sederajat) dalam artian bahwa perkawinan yang dilaksanakan sebaiknya dengan orang dari wangsa atau kasta yang sama. Hal tersebut mengindikasikan bahwa perkawinan adat Bali cenderung bersifat endogami klan. Maka dari itu, perkawinan antarwangsa tidak dianjurkan dalam perkawinan adat

${ }^{8}$ Bhasin, K dan N. S. Khan.1995. Persoalan Pokok mengenai Feminisme dan Revolusinya.Jakarta: PT. Gramedia Pustaka Utama.

9Sadnyini, Ida Ayu. 2016. Sanksi Perkawinan Terlarang Di Bali Dulu dan Kini. Denpasar: Udayana University Press 
Bali.Terlebih lagi, jika perkawinan tersebut terjadi pada perempuan dari wangsa lebih tinggi dengan laki-laki yang memiliki wangsa lebih rendah darinya.

Ada dua bentuk perkawinan pratiloma yang dikenal dalam perkawinan adat Bali, yaitu perkawinan asu pundung dan alangkahi karang hulu. Perkawinan asu pundung adalah perkawinan yang dilakukan oleh perempuan dari wangsa Brahmana dengan laki-laki dari wangsa Ksatrya, Waisya, dan Sudra. Sementara, yang dimaksud dengan perkawinan alangkahi karang hulu adalah perkawinan yang dilakukan oleh perempuan dari wangsa Ksatrya dengan laki-laki dari wangsa Waisya dan Sudra, serta perkawinan yang dilakukan oleh perempuan dari wangsa Waisya dengan laki-laki dari wangsa Sudra (Paswaran DPRD No. 11 Tahun 1951 dari Atmaja, 2008: 149).

Perkawinan anuloma dan pratiloma memiliki tata cara yang berbeda dalam melangsungkan upacaranya. Hal ini dipengaruhi oleh status sosial yang dimiliki oleh pihak laki-laki. Seperti yang sudah diuraikan sebelumnya, ada empat cara perkawinan di dalam perkawinan adat Bali, yaitu perkawinan mapadik (meminang), perkawinan kejangkepan (dijodohkan), perkawinan merangkat atau nyerorod (kawin lari), dan perkawinan pada gelahang. Mapadik atau meminang merupakan istilah yang digunakan apabila perkawinan tersebut dilangsungkan antara laki-laki dan perempuan dengan wangsa yang sama (pepadan) atau bila perkawinan tersebut dilakukan oleh laki-laki dari wangsa yang lebih tinggi dengan perempuan dari wangsa yang lebih rendah. Sementara perkawinan kejangkepan merupakan perkawinan yang terjadi dari hasil perjodohan yang dilakukan oleh kedua orang tua calon mempelai. Sedangkan yang dimaksud dengan perkawinan merangkat atau nyerorod adalah perkawinan yang terjadi apabila pihak perempuan memiliki wangsa yang lebih tinggi dari laki-lakinya. Terakhir adalah perkawinan pada gelahang. Perkawinan pada gelahang adalah perkawinan yang terjadi apabila si mempelai perempuan dan mempelai laki-laki sama-sama merupakan anak tunggal. Oleh karena itu, pasangan tersebut memiliki dua kewajiban (ayah-ayahan) baik itu di desa sang mempelai perempuan maupun di desa si mempelai laki-laki. Hal tersebut oleh masyarakat setempat disebut dengan istilah negen dadua.

Berkaitan dengan perkawinan dengan caramepadik, ada beberapa tahapan yang harus dilewati sebelum sepasang mempelai dikawinkan. Mapadik sendiri berasal dari padik yang berarti pinang atau lamar. Sehingga mapadik sendiri dapat diartikan sebagai upaya meminta seorang gadis untuk dikawinkan dengan seorang pria. Upaya tersebut dilakukan oleh orang tua atau keluarga calon mempelai pria.Prosesi mepadik harus melewati tahapan yang terdiri dari bungkah (awal), madia (tengah), dan tugtug (akhir).

Pada tahap bungkah (awal) keluarga calon mempelai laki-laki akan mendatangi rumah calon mempelai perempuan untuk menyampaikan niatnya meminang si gadis. Tahap selanjutnya yaitu tahap madia, dimana dalam tahapan ini terjadi kesepakatankesepakatan diantara kedua belah pihak terkait dengan lamaran yang dilakukan. Sehingga pada tahap ini kedua belah pihak (yang melamar dan yang dilamar) sudah memperoleh kesepakatan apakah lamaran tersebut diterima atau ditolak. Jika lamaran yang dilakukan oleh pihak laki-laki diterima, tahap selanjutnya yaitu tugtug sebagai tahap akhir dari prosesi mepadik.

Pada tahap tugtug pihak keluarga calon mempelai laki-laki akan kembali mendatangi rumah keluarga calon mempelai perempuan dengan disertai iring-iringan pihak keluarga besar untuk membawa tetukon, basan pupur, dan raja panomah. Tetukon 
adalah materi pemberian keluarga pria yang terdiri dari seperangkat busana wanita beserta perhiasan, yang bobot nilainya sepadan dengan tingkat sosial yang bersangkutan. Penyerahan tetukon kepada pihak keluarga calon mempelai perempuan yang dilakukan oleh pihak keluarga calon mempelai laki-laki sebagai simbol bahwa pertunangan sudah dilakukan dan si gadis yang sudah dilamar akanmenjadi "gadis terlarang". Pasca prosesi mepadik, perkawinan paling lambat dilaksanakan dalam kurun waktu enam bulan.

Seperti yang sudah diungkapkan sebelumnya bahwa prosesi mepadik tidak hanya dilakukan pada perkawinan pepadan (sederajat/wangsa yang sama), tetapi juga dapat dilakukan jika calon mempelai laki-laki memiliki wangsa yang lebih tinggi dari pihak perempuan. Ketika perkawinan terjadi pada perempuan yang berasal dari wangsa lebih rendah dari laki-lakinya, maka perempuan tersebut melewati tahap yang disebut dengan mének wangi (mének berarti naik, dan wangi berarti harum).Mének wangi disimbolkan sebagai prosesi menaikkan derajat seorang perempuan yang menikah dengan laki-laki dari wangsa yang lebih tinggi. Setelah perkawinan dilangsungkan, perempuan tersebut tidak lagi memakai namanya sewaktu gadis, melainkan dipanggil dengan sebuatan jero.

Dengan meningkatnya derajat perempuan tersebut menjadi jero, maka nama panggilannya diganti sesuai statusnya yang baru. Misalnya, Ni Wayan Dastri, perempuan jaba yang dikawini oleh seorang laki-laki Triwangsa, diganti namanya menjadi Jero Ratna, dan sebagainya, yang biasanya menggunakan nama-nama bunga. Meskipun seolah adanya peningkatan status sosial dari perempuan yang menikah dengan laki-laki dari wangsa yang lebih tinggi, tapi di sisi lain hal tersebut justru merupakan bentuk diskriminasi yang dialami perempuan. Hal ini karena, perempuan yang menjadi jero akan kehilangan identitasnya karena adanya perubahan nama yang dialami oleh perempuan tersebut.

Konsekuensi lain yang harus dihadapi oleh perempuan yang menjadi jero menurut Sadnyini ${ }^{5}$, antara lain, saat dilangsungkannya upacara perkawinan sesajen yang digunakan saat perkawinan tersebut diletakkan secara terpisah antara sesajen yang diperuntukkan bagi mempelai laki-laki dan sesajen untuk mempelai perempuan. Bekas sesajen yang diperuntukkan bagi mempelai perempuan tidak akan diterima (dikonsumsi) oleh keluarga suaminya, melainkan akan diberikan kepada keluarga mempelai perempuan atau kerabat terdekat suami yang memiliki wangsa sama atau lebih rendah dari sang mempelai perempuan. Tidak hanya sampai disitu saja, diskriminasi yang diterima oleh perempuan yang menjadi jero terlihat dari adanya larangan melakukan kewajiban mendoakan (nyumbah) roh orang tua kandungnya saat upacara ngaben/ upacara kematian.

Selain itu, perempuan yang menjadi jero juga diwajibkan menggunakan bahasa Bali halus untuk berbicara dengan keluarga suaminya dan juga pada anakanaknya.Pemaknaan terhadap konsep mének wangi hanya berlaku bagi keluarga perempuan.Artiannya setelah seorang perempuan menjadi jero, keluarga dari perempuan tersebut diwajibkan untuk menggunakan bahasa Bali halus saat berbicara dengan perempuan tersebut. Meskipun telah menjadi bagian dari keluarga suaminya, akan tetapi kedudukan dari perempuan yang menjadi jero tidaklah sama dengan

5 ibid, hal 5 
perempuan yang sederajat. Demikian pula dengan hak-hak yang diterimanya, dibatasi oleh etika-etika yang berlaku di rumah suaminya.

Di sisi lain saat pergi ke rumah keluarganya, perempuan yang menjadi jero tidak lagi diperlakukan sama oleh keluarganya. Cenderung keluarga akan menunjukkan sikap antipati. Ini disebabkan karena adanya perubahan struktur bahasa yang digunakan, yang juga berpengaruh terhadap tindakan-tindakan yang ditunjukkan. Karena statusnya yang kini sudah meningkat, maka perempuan tersebut tidak lagi diperkenankan makan bersama-sama dengan keluarganya. Keluarganya pun tidak lagi bisa memanggilnya dengan namanya saat gadis, tetapi harus memanggilnya dengan sebutan jero. Berasarkan ilustrasi tersebut terlihat bahwa perempuan yang melakukan perkawinan dengan laki-laki dari wangsa yang lebih tinggi mengalami kondisi yang dilematis. Disatu sisi mereka belum diterima sepenuhnya di rumah suaminya, tapi di sisi lain mereka sudah kehilangan hak-haknya di rumah orang tuanya.

Berbeda dengan perkawinan yang dilakukan dengan caramepadik dalam perkawinan anuloma, pada perkawinan asu pundung dan alangkahi karang hulu perempuan yang akan dikawinkan tidaklah dipinang melainkan dibawa lari oleh calon mempelai laki-laki ke rumah orang tua mempelai laki-laki untuk selanjutnya dilakukan prosesi upacara perkawinan. Cara perkawinan yang demikian disebut juga dengan istilah nyerorod/merangkat. Hal ini dilakukan karena perkawinan tersebut tidak memperoleh restu dari pihak keluarga perempuan. Biasanya hal tersebut disebabkan status sosial (wangsa) pihak laki-laki lebih rendah dari pihak perempuan. Akan tetapi, perkawinan nyerorod akan berkorelasi dengan hilangnya martabat seorang perempuan saat dilangsungkannya perkawinan tersebut. Hal ini terlihat dari konsekuensi yang diterima perempuan yang melakukan perkawinan asu pundung dan alangkahi karang hulu diwajibkan melakukan prosesi patiwangi (pati berarti mati, padam dan wangi berarti harum).

Prosesi patiwangi dimaksudkan sebagai simbol hilangnya hak-hak perempuan tersebut sebagai perempuan dari wangsa yang lebih tinggi.Selain itu, prosesi patiwangi dilakukan karena dianggap telah melanggar nilai-nilai adat yang telah diwariskan secara turun-temurun. Setelah memutuskan untuk melakukan perkawinan dengan laki-laki dari wangsa yang lebih rendah darinya, perempuan tersebut akan mengikuti status sosial dari suaminya. Hal tersebut berdampak pada berubahnya relasi antara perempuan tersebut dengan keluarganya. Bagi sebagian perempuan yang melakukan perkawinan asupundung dan alangkhi karang hulu mereka dilarang untuk mengunjungi keluarganya, sekalipun jika mereka ingin mengunjungi keluarganya mereka harus menunggu selama enam bulan. Selain itu, perempuan yang melakukan perkawinan nyerorod diwajibkan untuk menggunakan bahasa Bali halus saat berbicara dengan keluarga suaminya. Demikian pula dengan perilakunya saat datang ke rumah orang tuanya diatur berdasarkan etika pergaulan kaum Triwangsa.

Hingga saat ini, perkawinan nyerorod/merangkat masih menimbulkan gejolak di masyarakat. Hal ini disebabkan karena perkawinan nyerorod/merangkat dianggap menyalahi tatanan sosial di masyarakat. Sebelum adanya Keputusan DPRD Bali Nomor 11 Tahun 1951 tentang perkawinan antara Catur Wangsa di Bali, para pelaku perkawinan antarwangsa (asu pundung dan alangkahi karang hulu) memperoleh sanksi adat yang berat. Sanksi yang dulu pernah diterapkan pada pelaku perkawinan asu pundung dan alangkahi karang hulu antara lain sanksi melabuh geni atau terjun ke dalam 
api, melebok atau dibuang ke dalam laut dengan kaki diikat/digandoli dengan batu, dan sanksi selong atau dibuang ke suatu daerah. Meskipun saat ini sanksi tersebut tidak lagi diterapkan, akan tetapi secara sosiologis masih ada beberapa masyarakat yang menerapkan sanksi sosial bagi pelaku perkawinan asu pundung dan alangkahi karanghulu.

Perempuan yang melakukan perkawinan nyerorod sering dipandang sebelah mata karena perempuan yang melakukan perkawinan dengan cara nyerorod seolaholah mendatangi laki-laki. Bahkan tidak jarang perempuan yang melakukan perkawinan dengan caranyerorod dipandang sebagai perempuan yang diambil di sembarangan tempat karena perkawinannya tidak direstui dan tidak dilepaskan oleh keluarganya. Dampak dari adanya stigma tersebut adalah tidak dihargainya perempuan di rumah suaminya. Di sisi lain dengan melakukan perkawinan dengan caranyerorod menimbulkan kesan bahwa harga diri perempuan rendah/jatuh di mata masyarakat.

\section{HASIL DAN PEMBAHASAN}

\section{Hasil Pesamuan Agung III \{Majelis Utama Desa Pakraman (MDP) Bali\}}

Sebelumtahun 1900an perempuan Bali memiliki status yang sangat rendah (pers. Com, Windia, 28 Juli 2016) hingga harus pula menceburkan diri ke api pembakaran mayat suaminya (mesatya). Saat itu dapat dikatakan hingga nyawa istripun (biasanya selir atau permaisuri raja) harus hilang bersama wafatnya sang suami. Penjajah Belanda telah menghapuskan tradisi mesayta tersebut.

Pencerahan yang dibawa oleh Raden Adjeng Kartini memungkinkan perempuan Bali mengecap pendidikan tinggi, bekerja di ranah publik, dirinya-pun harus pula sempurna di ranah domestik (menyiapkan sarana upacara agama, merawat keluarga luas suami dan keluarga intinya). Sebelum adanya keputusan Pesamuhan Agung MUDP Bali, nilai-nilai yang berlaku dalam hukum agama Hindu adalah konteks kapurusa bahwa harta warisan dilanjutkan hanya kepada ahli waris laki-laki saja, sedangkan perempuan hanya mendapatkan pemberian yang disebut harta bawaan (tatadan) yang pemberiannya tergantung kepada kedudukan ahli waris lakilaki.Keluarga modern memberikan pendidikan ke jenjang yang lebih tinggi kepada anak perempuan selain harta bawaan ayah dan ibunya.

Dalam sistem pewarisan di Bali, pencatatan harta pusaka dibagi tiga yaitu:

1. Harta Pusaka Leluhur (tetamian)

2. Harta bersama suami-istri (gunakaya)

3. Harta bawaaan dari masing-masing suami-istri (tatadan)

Adat Bali terutama hukum warisnya kini memasuki era baru.Dulu perempuan Balitidak berhak atas warisan dari orang tuanya, kini perempuan Bali memiliki setengah dari hak waris yang diberikan kepada saudara laki-lakinya. Ketentuan mengenai hak waris perempuan Bali ini merupakan hasil Pesamuhan Agung III yang digelar pada 15 Oktober 2010 dan dituangkan dalam Keputusan Pesamuhan Agung MUDP Bali Nomor 01/KEP/PSM-3/MDP Bali/X/2010. Perempuan Bali mendapat tempat dalam mengurus dan meneruskan swadharma atau tanggung jawab keluarga dengan Pesamuhan Agung mengatur ketentuan baru terkait hak ahli waris bagi kaum perempuan (predana). Keputusan ini kini terus disosialisasikan ke desa-desa pakraman di seluruh Bali agar ditindaklanjuti dengan mengadopsinya ke dalam awig-awig atau pararem yang bagi masyarakat awam atau penduduk non Bali perlu dipelajari kembali 
sebagai bentuk transformasi sosial posisi perempuan Bali yang tengah mengalami peningkatan.

Walaupun demikian proses perubahannya, dalam Keputusan Pesamuhan Agung MUDP Bali itu memilah kondisi aturan bagi perempuan yang telah menikah. Ahli waris yang kawin ke luar dan berstatus pradana atau tidak berada di rumah --dalam istilah Bali disebut ninggal kadaton terbatas--, berhak atas sepertiga dari warisan gunakaya (hasil kerja/harta gono gini) orang tuanya, setelah dikurangi sepertiga untuk duwe tengah atau dana untuk perawatan orang tua. Dengan kata lain, perempuan mendapat setengah dari harta warisan gunakaya yang diterima oleh saudara lakilakinya yang berstatus purusa.

Lebih sulit bagi perempuan Bali yang karena menikah dan mengikuti agama suaminya, maka posisinya jatuh di mata keluarga. Ahli waris ini dikategorikan ninggal kadaton penuh atau pindah agama dan tidak berhak sama sekali atas harta warisan, tetapi ia dapat diberikan bekal (jiwa dana) oleh orang tuanya. Biasanya bekal (berbentuk benda seperti emas, kendaraan atau uang yang diberikan sebelum pernikahan atau upacara perkawinan sesuai suaminya yang non Hindu itu.

Ciri pada pewarisan keluarga yang tidak memiliki anak laki-laki adalah anak perempuannya diminta kawin kaceburin/nyentana atau mengambil sentana rajek ${ }^{10}$ yaitu jika terjadi satu pasangan hanya memiliki satu putri tunggal yang ketika menuju pernikahan, sang ayah yang sedang menghadap maut sempat meminta kesediaan pacar putrinya untuk nyentana atau berada pada status perempuan (tidak berlaku di Buleleng, Gianyar dan Karangasem). Maka perempuan yang meminta sentana statusnya mipil yang terdaftar dalam desa adat (kasus A). Artinya sebagai perempuan kapurusa dirinya atau perempuan yang mendapat pengukuhan melanjutkan tugas dan tanggung jawab swadharma orang tua tanpa keluhan sang suami (lihat kasus B). Karena sang suami telah melakukan sentana rajek/laki-laki dalam posisi diadopsi oleh keluarga istrinya. Secara hukum positif, perempuan ini membayar pajak bumi dan bangunan rumah keluarga mendiang ayahnya, menyelenggarakan upacara agama Hindu lengkap dengan dana punia/derma yang harus tersedia dan menyiapkan dana untuk upacara pengabenan atau kremasi ibunya yang menjanda. Perempuan ini menjadi warga aktif secara adat (Etzioni) walaupun kadang menimbulkan belas kasihan warga desa terhadap suaminya yang berdiri di sebelah kiri sebagai simbol posisi perempuan.

Jelaslah bahwa harta tetamian (harta pusaka atau leluhur), tetap melekat pada purusa atau pihak laki-laki karena dalam ajaran agama Hindu, swadharma atau tanggung jawab diberikan kepada anak laki-laki dan dia yang mempunyai kewajiban material dan immaterial dalam keluarga besarnya. Namun dalam kasus sentana rajek, harta tetamian melekat kepada kapurusa yang secara fisik adalah pradana atau putri tunggal dari keluarga tersebut.

\section{Perempuan yang Bercerai}

Mulih daha berarti "kembali gadis" yang dalam kasus perceraian, adalah kembalinya seorang putri kepada keluarga aslinya. Mulih berarti kepulangan yang disepakati pihak laki atau perempuan untuk dapat kembali ke rumah remajanya

${ }^{10}$ Artadi, 2012. Hukum Adat Bali dengan aneka masalahnya. Denpasar: Pustaka Bali Post 
dengan hak dan kewajiban yang sama. Kedua suami-istri yang bercerai berhak atas pembagian harta bersama dengan prinsip bagi rata. Anak bisa diasuh pihak ibu tanpa memutuskan hubungan hukum dan kekeluargaan dari pihak ayah.

Bagi perempuan atau laki-laki yang bercerai, "Aturan ini lebih baik dibanding aturan pewarisan lain seperti Paswara 1900 pada zaman kolonial dan awig-awig desa pekraman lainnya yang tak mengatur secara jelas hal ini," kata Windia (Jagadhita, www.balisaja.com 2015). Ketentuan hak waris perempuan Bali diharapkan dapat segera diatur dalam pararem atau kesepakatan bersama di setiap desa adat. Tujuan sosialisasi aturan ini adalah bagi bendesa (kepala desa adat) untuk dapat segera memasukkan ketentuan ini dalam pararem dan awig-awig (ketentuan tertulis) yang menerima kehadiran para janda dalam lingkungan keluarga asalnya.

Keputusan Pasamuhan Agung III Majelis Desa Pakraman Bali dengan ketentuan perceraian sebagai berikut:

a. Pasangan suami-istri yang akan melangsungkan perceraian, harus menyampaikan kehendaknya (baca: bercerai) itu kepada prajuru banjar atau desa pakraman. Prajuru wajib memberikan nasihat untuk mencegah terjadinya perceraian.

b. Apa bila terjadi perceraian maka terlebih dahulu harus diselesaikan melalui proses adat, kemudian dilanjutkan dengan mengajukan ke pengadilan negeri untuk memperoleh keputusan.

c. Menyampaikan salinan (copy) putusan perceraian pengadilan atau akte perceraian kepada prajuru banjar atau desa pakraman. Pada saat yang bersamaan, prajuru banjar atau desa pakraman menyarankan kepada warga yang telah bercerai supaya melakukan upacara perceraian sesuai dengan agama Hindu.

d. Prajuru mengumumkan (nyobyahang) dalam rapat banjar atau rapat desa pakraman bahwa pasangan suami istri bersangkutan telah bercerai secara sah menurut hukum nasional atau hukum adat Bali, sekalian menjelaskan swadharma dari masing-masing mantan pasangan suami istri tersebut di banjar atau desa pakraman, setelah perceraian (MUDP, 2010: 46-47).

Akibat dari perubahan hukum perceraian ini kemudian diatur status baru dari pasangan yang bercerai sebagai berikut:

a. Setelah perceraian, pihak yang berstatus Pradana (istri dalam perkawinan biasa atau suami dalam perkawinan nyeburin) kembali ke rumah asalnya dengan status mulih daha dan mulih teruna, sehingga kembali melaksanakan swadharma (kewajiban) berikut swadikara (hak)-nya dilingkungan keluarga asal.

b. Masing-masing pihak berhak atas pembagian harta gunakaya (harta bersama dalam perkawinan) dengan prinsip pedum pada (dibagi sama rata).

c. Setelah perceraian, anak yang dilahirkan dapat diasuh oleh ibunya, tanpa memutuskan hukum dan hubungan pasidikaran (darah) anak tersebut dengan keluarga purusa, dan oleh karena itu anak tersebut mendapat jaminan hidup dari pihak purusa (MUDP, 2010: 47).

Sebagai contoh, pembagian hak waris yang sama sejak lama sudah diberlakukan di desa Bali Aga, Tenganan Pegringsingan, Kecamatan Manggis, Kabupaten Karangasem. Desa kuno ini menganut sistem pewarisan parental. Baik 
anak laki-laki maupun perempuan mendapatkan hak waris yang sama. Tak ada pembedaan dengan sistem pembagian yang adil. Warisan dibagi setelah dipotong biaya upacara orangtuanya yang meninggal. Sementara rumah yang ditinggalkan akan menjadi hak dari anak yang terkecil. Namun yang diwarisi itu bukan saja harta benda jikalau orangtuanya itu memiliki utang, mereka juga harus menanggungnya.Kondisi anak terkecil menempati dan mewarisi rumah orang tua dikatakan sebagai sistem pewarisan minorat. Di daerah Bangli berlaku sistem pewarisan mayorat, dimana putra pertama atau tertua mewarisi tanah dan bangunan keluarganya serta berkewajiban menjalankan swadharma dengan mempertahankan tradisi dan upacara adat dan agama Hindu.

Dalam kasus perempuan yang bercerai dan 'mulih daha' maka keberterimaan kehadirannya kembali di rumah asalnya adalah karena belas kasihan. Windia (2016) menyatakan bahwa 'mulih daha' adalah fenomena kemanusiaan yang harus diterima baik oleh keluarga inti (ayah ibu) atau bila kedua orang tua telah tiada, peran kemanusiaan mayorat atau minorat dari saudara kandung laki-lakinya adalah tolak ukur sistem kekeluargaan (menyama-braya) di Bali.

\section{Janda ditinggal Mati}

Surat edaran hasil diskusi hukum adat di Bali tertanggal 4 Maret 1971 menyimpulkan bahwa "Janda bukan sebagai ahli waris, ia hanya berhak menikmati harta bagian suami". Artadi11 seorang pakar hukum adat di Bali mempertanyakan "sudah sesuaikah dengan perasaan keadilan masyarakat Bali jika janda tinggal mati digariskan kedudukannya seperti diatas, walaupun Mahkamah Agung RI pada prinsipnya tetap menghendaki 'janda adalah ahli waris'".

Masalah hak waris di Bali adalah masalah kompleks mengenai kedudukan suami istri dan anak terhadap harta pusaka dan harta gunakaya. Apa bila seorang janda berada dalam posisi memiliki suami yang dalam keluarganya adalah anak tertua dengan sistem pewarisan mayorat, menurut hukum adat Bali, sejatinya tak hanya membagi harta warisan tapi mengandung arti pelestarian dan pengurusan kewajiban pewaris. Janda tersebut berhak atas warisan dengan status ninggal kedaton terbatas, juga bila dia tidak mempunyai anak laki-laki dan meminta suami dari putrinya nyentana, maka sang menantu berhak atas harta warisan dan apa bila yang bersangkutan memiliki anak angkat, jatuh pula kepadanya asas ategen asuwun (dua banding satu). Dua bagian bagi laki-laki dan satu bagian bagi kaum perempuan.

Misalnya Kasus A, ada tiga orang ahli waris syah dengan ibunya seorang janda yang sakit-sakitan. Putri pertama (seorang bidan muda) adalah anak yang melanjutkan swadharma orang tuanya karena pengukuhan purusa telah meminta putri pertama ini mengambil sentana (suami yang diadopsi sebagai pradana).Sehingga ada empat orang yang berhak sebagai ahli waris yaitu; ibu janda yang ditinggal mati suaminya, putri pertama yang menjadi purusa dengan suami sebagai sentana pradana dan putri bungsu.Warisan ategen asuwun ini dibagi empat orang yang berasal dari dua pertiga harta gunakaya (istilah lazim harta bersama suami yang meninggal dunia dan istri yang ditinggalkannya atau harta gono-gini).

Mengapa harta bawaan suami istri itu hanya dibagi dua pertiga? Karena sepertiga harta gono gini itu dijadikan penambah duwe tengah (milik kedua belah pihak

11 Ibid, hal 59 
sebagai tambahan harta pusaka dan dana memelihara leluhur). Tidak hanya itu, sang menantu adopsi mendapat bagian juga yaitu harta gunakaya dibagi sama dengan ketiga perempuan di keluarga itu. Putri kedua/bungsu maupun ibu mereka yang janda hanya berhak tinggal sementara di rumah tua (di desa asal misalnya di daerah Tabanan) yang putri bungsu tersebut sambil melanjutkan sekolahnya tinggal bersama kakak kandung, kakak adopsi dan sang ibu di rumah lain (harta bawaan). Apa bila kelak putri bungsu ini menikah secara biasa (tanpa berpindah agama) maka dia tidak berhak lagi tinggal di rumah tua maupun rumah klan/keluarga asli. Dia harus ikut suami dan apa lagi bila si bungsu menikah dan berpindah agama maka ia tidak lagi dianggap sebagai ahli waris, hilanglah haknya atas penjualan rumah harta bawaan ibunya yang janda tersebut.

Kasus ini menarik ditinjau dari kajian sosiologi kontemporer yang mengajak masyarakat Bali untuk melakukan tuntunan diri (self guiding) sebagai masyarakat aktif (Etzioni, 1968) dan memberikan ruang bagi perempuan Bali untuk menjadi wajib pajak yang aktif. Kasus B, sentana rajek adalah perkawinan putri tunggal sebut saja Ayu yang menjadi kapurusa (status ahli waris laki-laki). Misalnya perkawinan ini ajek dan secara adat mendapat dukungan, maka Ayu dapat menjalankan kewajiban perpajakan daerah dengan membayar pajak bumi dan bangunan serta membayar dana punia (pajak keagamaan) yang diwariskan kedua orang tuanya.

Putri dan Bagus pada kasus lainnya, menikah dengan status keduanya menjadi purusa dikenal dengan perkawinan padagelahang. Artinya status perkawinan adat kedua pasangan ini memungkinkan mereka masing-masing menjadi wajib pajak aktif. Baik Ayu maupun Bagus telah menjadi warga yang aktif memenuhi kewajiban perpajakan daerah, terutama dalam membayar pajak bumi dan bangunan serta membayar retribusi daerah (dana kebersihan, dana lingkungan dll). Dengan kata lain, hukum adat yang mendapat revisi dan perbaikan secara terus menerus akan menjadikan warganya aktif partisipatif tanpa bias-bias gender yang menyebabkan satu posisi gender lebih rendah dari pada biner gender yang lainnya.

Jagadhita (2015, www.balisaja.com) mengingatkan agar warga adat di desadesa Pakraman Bali mengutamakan musyawarah mufakat, sesuai dengan anjuran pakar hukum adat Bali yang juga Nayaka MUDP Provinsi Bali, Wayan P. Windia. Windia menyatakan Keputusan Majelis Utama Desa Pekraman (MUDP) pada 2010 yang bisa menjadi rujukan penyelesaian perkara soal waris menurut hukum adat Bali. "Hakim dan pihak bersengketa disarankan mengutamakan keputusan MUDP dari pada rujukan lain yang sebelumnya berlaku," tambahnya. Tentunya keputusan baru ini lebih memberikan keadilan kepada perempuan karena memberikan kepastian tentang kedudukan istri dan anak terhadap warisan saat berumahtangga dan jika bercerai atau ditinggal mati oleh suami.

\section{SIMPULAN DAN SARAN}

Sistem wangsa yang berlaku di Bali memiliki implikasi yang cukup besar terhadap perkawinan yang terjadi di Bali. Berlakunya sistem wangsa dalam kehidupan masyarakat Bali, menjadikan perkawinan yang dianjurkan berdasarkan hal tersebut adalah perkawinan pepadan (sederajat atau dengan wangsa yang sama). Meskipun tidak dapat dipungkiri bahwa perkawinan antarwangsa terjadi dalam perkawinan adat Bali. Ada dua bentuk perkawinan antarwangsa, yaitu perkawinan anuloma dan patriloma. 
Perkawinan anuloma adalah perkawinan yang terjadi antara laki-laki dari wangsa yang lebih tinggi dengan perempuan dari wangsa yang lebih rendah. Sedangkan perkawinan patiloma yang terdiri dari perkawinan asu pundung dan alangkahi karang hulu adalah perkawinan yang dilakukan oleh perempuan dari wangsa yang lebih tinggi dengan laki-laki dari wangsa yang lebih rendah. Kedua bentuk perkawinan tersebut menimbulkan diskriminasi terhadap perempuan Bali yang disebabkan adanya perkawinan antarwangsa. Perkawinan anuloma telah menyebabkan hilangnya identitas perempuan Bali yang disebabkan adanya perubahan nama karena pernikahan tersebut. Tidak hanya hilangnya identitas pada perempuan yang melakukan perkawinan anuloma hak-haknya sebagai anak dan juga istri pun menjadi kian terbatas.

Diskriminasi yang dialami oleh perempuan tidak hanya dalam perkawinan pratiloma, tetapi juga dalam perkawinan asu pundung dan alangkahi karang hulu.Pada pernikahan tersebut perempuan dilarang untuk mengunjungi keluarganya.Selain itu, perempuan yang melakukan perkawinan asu pundung dan alangkahi karang hulu diwajibkan untuk menggunakan bahasa Bali halus saat berbicara dengan keluarganya. Demikian pula dengan perilakunya saat datang ke rumah orang tuanya diatur berdasarkan etika pergaulan kaum Triwangsa. Perempuan yang melakukan perkawinan asu pundung dan alangkahi karang hulu seolah tidak memiliki harga diri dan martabat karena perkawinannya dilaksanakan dengan caranyerorod dan tidak memperoleh restu dari orang tua pihak perempuan. Kondisi tersebut menjadikan perempuan Bali yang melakukan perkawinan asu pundung dan alangkahi karang hulu tidak dihargai di rumah suaminya. Bagi perempuan yang menikah dengan berpindah agama ke selain Hindu, baginya tidak ada lagi hak waris akibat restu orang tuanya telah hilang dan saudara laki-lakinya tidak perduli lagi kepadanya.

Sementara di sisi lain fenomena pewarisan ategen asuwun di Bali memungkinkan posisi perempuan Bali meningkat dan setara dengan posisi perempuan lain di luar Bali. Pada banyak kasus persengketaan dan pertikaian hak waris, pelakunya adalah kaum laki-laki. Perempuan Bali sejak lama tidak bersuara dan tidak pula mencoba memaksakan kehendaknya mendapat bagian dari sistem waris itu. Secara kasat mata budaya patriarkhi melekat kuat dalam kepemilikan tanah dan bangunan.Kini dengan perempuan mendapatkan hak waris sebagian dari saudara prianya atas keputusan MUDP, posisinya di mata adat desa pakraman telah inklusif. Perempuan berhak menjadi wajib pajak dan membayar kewajiban pajak bumi dan bangunan rumah dan tanah warisan orang tuanya.

\section{REFERENSI}

Artadi, IK, 2012. Hukum Adat Bali dengan aneka masalahnya. Denpasar: Pustaka Bali Post

Atmaja, Jiwa. 2008. Bias Gender Perkawinan Terlarang Pada Masyarakat Bali. Denpasar: Udayana University Press

Bhasin, K dan N. S. Khan.1995. Persoalan Pokok mengenai Feminisme dan Revolusinya.Jakarta: PT. Gramedia Pustaka Utama. 
Fiansyah, R 2016. Kebijakan Pajak Rugikan Perempuan yang Bekerja, http://ekbis.sindonews.com/read/1080737/33/kebijakan-pajak-rugikanperempuan-yang-bekerja-1453907391 diunduh tanggal 10 Juni 2016

Goode, William J. 2007. Sosiologi Keluarga. Jakarta: Bumi Aksara

Jagadhita, P. 2015. Perempuan Bali Kini Berhak dapat Warisan, Begini

Perhitungannya, diambil dari http://www.balisaja.com/2015/12/perempuanbali-kini-berhak-dapat.htmldiunduh tanggal 30 Juni 2016

Jaman, I Gede.Membina Keluarga Sejahtera (Grha Jagatdhita). Surabaya: Paramita, 1998.

MUDP, 2011.Himpunan Hasil-hasil Pasamian Agung III MDP Bali.

Rhismawati, NL, (2013) Hak Waris Perempuan Bali Didesak Masuk Perarem diunduh dari http://www.antarabali.com/berita/38415/hak-warisperempuan-bali-didesak-masuk-perarem pada tanggal 20 Juni 2016

Sadnyini, Ida Ayu. 2016. Sanksi Perkawinan Terlarang Di Bali Dulu dan Kini. Denpasar: Udayana University Press

Sudarma, I Putu.Bias Gender dalam Perkawinan Beda Wangsa pada Masyarakat Hindu di Bali.Denpasar: Institut Hindu Dharma Negeri (IHDN)

Suryawati, Cok Istri. 2010. “Kepemimpinan Perempuan Pejuang Bali: Studi Kasus Ida I Dewa Agung Istri Kanya (Perspektif Kajian Budaya)".Program Pascasarjana Universitas Udayana. (Tesis belum terbit). 